\title{
RESULTS OF PALEOSTOMATOLOGICAL ANALYSIS OF MATERIAL FROM THE CAVE NEAR GORNJI VAKUF (SOUTH-WEST BOSNIA)
}

\author{
IZSLEDKI PALEOSTOMASTOLOŠKIH RAZISKAV GRADIVA \\ IZ JAME PRI GORNJEM VAKUFU (JUGOZAHODNA BOSNA)
}

\author{
Amila ZUKANOVIĆ ${ }^{1}$, Jasminko MULAOMEROVIĆ ${ }^{2} \&$ Damir MARJANOVIĆ $^{3}$
}

\begin{abstract}
UDK 903.5:572.7(497.6)

Amila Zukanović, Jasminko Mulaomerović \& Damir Marjanović: Results of paleostomatological analysis of material from the cave near Gornji Vakuf (South-West Bosnia)

Among explored speleological objects near the Krupa village, close to Gornji Vakuf, the most interesting cave from paleocultural aspect, is the cave named "Cave number 5 ". In the internal part of that cave, besides ceramic fragments and one metal needle, rich anthropological material have been found, compounds of numerous humans bones and teeth. Anato-morphological analysis of the one part of material showed that this site is a prehistoric crypt with remains of at least 13 people. Radiocarbon ${ }^{14} \mathrm{C}$ bone analysiss results showed that those people lived 2765 \pm 75 before presence. The fact that anthropological material includes some remains which belonged to children shows some characteristics of burial culture of that period on area of Uskoplje. This cave crypt is the one of the biggest on this region. Paleostomatological analysis of teeth and jaw fragments gave us clear evidence about therapeutic interventions performed in this period. X-rays analysis showed presence of the metal body inside the bone in one mandibular fragment. It's supposed that this metal is broken part of instrument used for tooth extraction.

Key words: cave burial, bone remains, ${ }^{14} \mathrm{C}$ method, paleostomatological analysis, Uskoplje, Bosnia.
\end{abstract}

Izvleček

UDK 903.5:572.7(497.6)

Amila Zukanović, Jasminko Mulaomerović \& Damir Marjanović: Izsledki paleostomastoloških raziskav gradiva iz jame pri Gornjem Vakufu (Jugozahodna Bosna)

Med vsemi raziskanimi speleološkimi objekti v bližini vasi Krupa, je s paleokulturnega vidika najbolj zanimiva »Jama št. 5 «. $\mathrm{V}$ notranjosti jame je bilo najdeno, poleg odlomkov lončevine in kovinske igle, tudi bogato antropološko gradivo, številne človeške kosti in zobje. Antropološko-morfološke preiskave dela tega gradiva kažejo, da gre za predzgodovinsko grobnico z ostanki najmanj 13 ljudi. Analiza kosti z radiokarbonsko analizo ${ }^{14} \mathrm{C}$ je pokazala, da so ti ljudje živeli $2765 \pm 75$ let pred sedanjostjo. Dejstvo, da antropološko gradivo vključuje tudi ostanke otrok, kaže značilnosti pokopavanja iz tega časa na območju Uskoplja. To jamsko grobišče je eno največjih s tega območja. Paleostomatološke preiskave zob in odlomkov čeljustnic nam jasno dokazujejo zdravstvene posege iz tistih časov. S pomočjo žarkov X je bil v kosti odlomka čeljustnice odkrit kovinski delec. Domnevno je ta kovinski delec odlomljeni del instrumenta, ki so ga uporabljali za ruvanje zob.

Ključne besede: jamsko grobišče, kostni ostanki, ${ }^{14} \mathrm{C}$, paleostomatološka preiskava, Uskoplje, Bosna.

\footnotetext{
${ }^{1}$ Faculty of Dentistry, University of Sarajevo, 71.000 Sarajevo, Bolnička 4a, Bosnia and Herzegovina , migulin@lsinter.net

${ }^{2}$ Speleological society „Speleo dodo”, 71000 Sarajevo, Branilaca Sarajeva 30, Bosnia and Herzegovina, jasminko.mulaomerovic@ bhtelecom.ba

${ }^{3}$ Institute for Genetic Engineering and Biotechnology, University of Sarajevo, Kemalbegova 10, 71.000 Sarajevo, Bosnia and Herzegovina, damir.marjanovic@ingeb.ba
}

Received/Prejeto: 07.02.2007 


\section{INTRODUCTION}

Speleologist of Bosnia and Herzegovina organized their traditional camp for year 2003 near Gornji Vakuf. Majority of exploration has been done in speleological objects around Bistrica and Krupa villages near Gornji Vakuf town (Figs. 1 and 2). As much as we know, speleological explorations of this area have been performed only in few caves near Krupa village, in period 1971-1973, for water supplying needs for Gornji Vakuf, and eventual touristic arrangement (Gašparović, 1979). Head of this research was Ratimir Gašparović, but his report of this research or any other maps of the objects are unknown. French engineer Albert Bordeaux (1987) who passed through this area about 1900 year, mentioned one cave and old mines in this part of Vranica mountain. Some speleological explorations probably also have been performed at the end of 1950's, during abounding geological researches of Vranica mountain, but also there's no evidence and data about that exploration. Amir Topčić from Gornji Vakuf started first explorations and recognitions of area of the west slope of Vranica in last few years (Topčić, 2000).

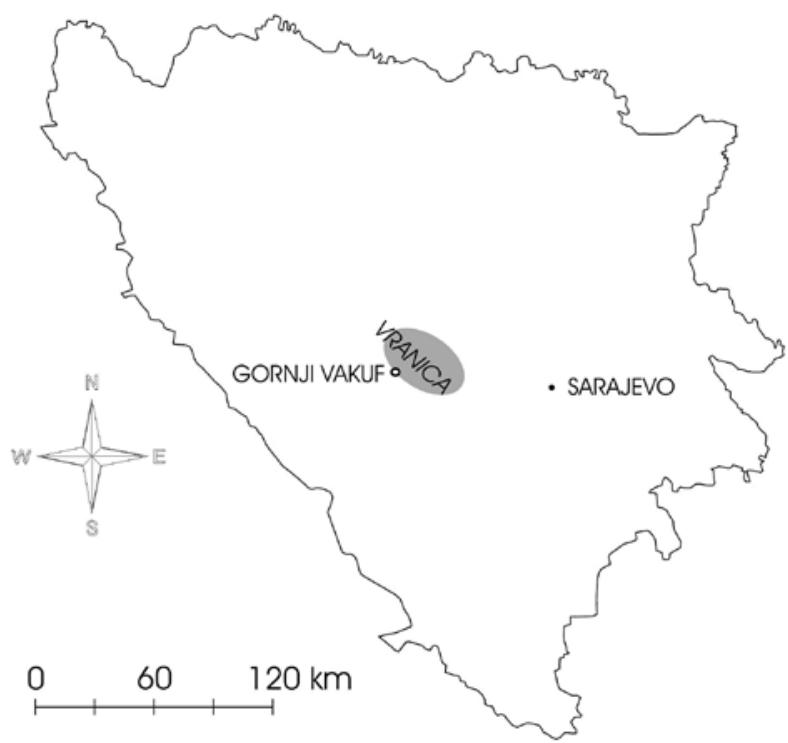

Fig. 1: Geographic position of Gornji Vakuf on the map of Bosnia and Herzegovina.

There are few things known about traces of human's culture in caves of this area. Archeological lexicon of Bosnia and Herzegovina doesn't mention any cave from this area. Old archeological site on the hill above source of Krušnica, with stone wall and ceramic fragments, its' dated in early iron age (Marijan, 1988). Franjo Martinčević (1901) noticed story of old man Matko from Bistrica which sad that some people from village enter in to the cave above source of Krušnica, and that one of the visitors found old ceramic pot on the cave shelf, which shouldn't take out because he was scared. A.Topčić found ceramic fragments in few caves, which are thought to have been in ceremonial proceedings. Because of that, during the speleological camp, special attention was given to those caves but also to the caves where we could expect similar founds. During field recognition, single pieces of ceramic were found under Baba Janja cave and Velika Pećina cave. We visited 8 caves with intention to collect data's about traces of human's culture. In Velika Pećina cave, Pećina in

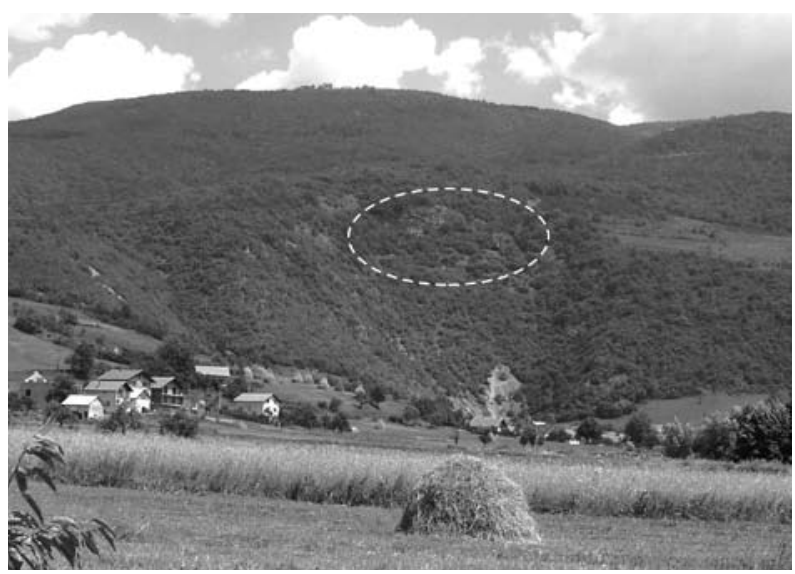

Fig. 2: Krupa village near Gornji Vakuf - at the bottom of the rock creep is the spring of Krušnica river; in marked part there are numerous caves entrances.

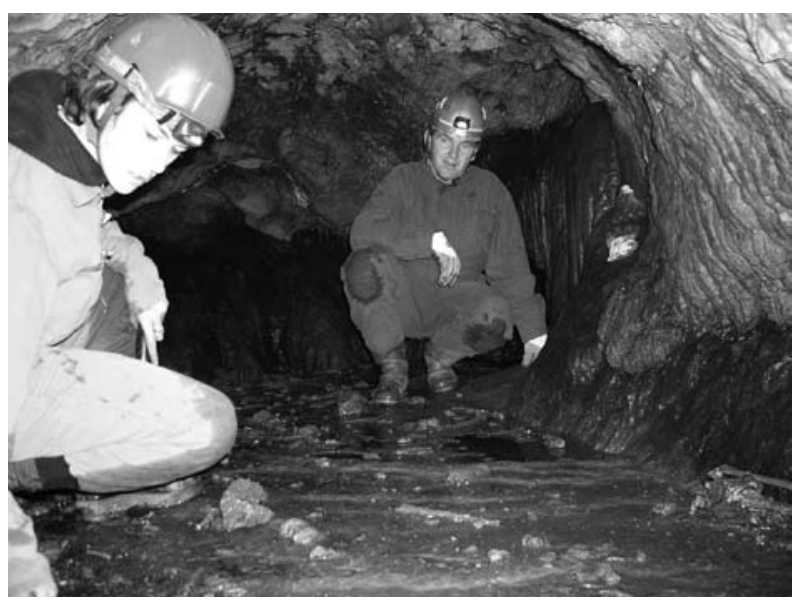

Fig. 3: The last part of the chanel with bones covered with cave sediments.

Guser, caves number 4, 5, 6 and 7 (marked with numbers cause they don't have names), Mala Pećina cave and Cave three entrances (Mulaomerović, 2004), it has been found few or less fragments of ceramic which showed continuity of living from bronze age till middle age. 
Cave number 5 is of course, considering founding till now, the most interesting cave, first at all because of findings of bigger number of human bones. $\left({ }^{*}\right)$ Along corridor inside the cave, also big number of ceramic fragments is found, which can be wide dated - from iron till middle age. Also, in the middle part of passage, 10 centimeters depth, one metal needle is found. Bones are found at the end of passage, at the space of 10-15 meters. Some of them are covered and fixed with cave sediments on the slope which is formed under one small chimney through which water easily passes. (Fig. 3).

On the first sight it's evident that all those bones belong to the rests of several people. Those are mostly fragments of bones of the human's trunk, skulls, upper and lower extremities and some permanent and decidual teeth. All bones and teeth are mixed all around the cave, probably because of the water activity. The biggest part of the bones is covered with cave sediments and by that fixed for the underlying surface, what unable collecting all material for analysis. The only material which could be taken for identification were bones and teeth placed in the water or in the clay, mostly near the cave's walls and bones which were just partially covered with sediments. Material is collected from 7 marked places.

\section{MATERIALS AND METHODS}

Found material presents fragments of skull bones (ossa cranii) - one part of left temporal bone, fragment of right temporal bone, two frontal bones (one fragment and one complete), right and left pelvic bone, and one part of right metacarpal bone (ossa membri inferioris), right forearm bone and part of left clavicular bone (ossa membri superioris), parts of jaw bones (4 fragments of mandibulae, one complete mandibula and one fragment of right maxilla), and 6 primary teeth (dentes decidui) and 30 permanent teeth (dentes permanentes).

All material first was mechanically cleaned with water and soft brush. Cave sediments from teeth were removed mechanically, using hand instruments for dental calculus scaling. One part of the bones which were covered with cave sediments was cleaned mechanically and rest was moved with acetyc acid suspension.

Material was analyzed using following methods:

- Anatomic-morphological analysis of bones and teeth:

For description of osteological findings, international anatomical nomenclature Terminologia Anatomica, from 1998. year has been used.

For morphological features of teeth crowns and roots, standards of Arizona State University Dental Anthropology System - ASU Dental Anthropology System (Christy et al, 1991) have been used.

For bones and teeth analysis, $4 \mathrm{X}$ magnifying lens has been used.

- Radiocarbon ${ }^{14} \mathrm{C}$ analysis for bone absolute age datation:

Age span is given in historical ages $(\mathrm{AD} / \mathrm{BC})$, with probability expressed in percentages, inside $1 \sigma$ mistake, and has been determined based on dendrochronological calibrating curve according to Stuiver \& Reimer (1986) and Bronk \& Ramsey (1995).
- Metrical and odontometric analysis of teeth and bone fragments:

All measurements was performed with millimeter measurer (Dentalschiebelehre) produced by Dentaurum company. Measures of each bone and each tooth were taken three times, in intervals of one month, after the mean of those individual measures was taken as final result. All measurements were performed by the same person.

- X -Rays analysis:

Jaws fragments and teeth are radiographicaly recorded and analyzed. Ortopantomograph OP100 machine produced by Instrumentarium company and Universal Oralix machine produced by Dentex company has been used for recording, using Kodak T-MAT E $(150 \times 300 \mathrm{~mm})$ and Kodak Insight Occlusal $(57 \times 76 \mathrm{~mm})$ $\mathrm{X}$-Ray films.

- DNA tooth extraction:

Optimized Qiagen extraction protocol was used for DNA extraction from tooth. DNA was determined and quantified by use of QuantiBlot ${ }^{\oplus}$ assay (Applied Biosystem, Foster City, CA, USA) (1996). The PowerPlex 16 kit (Promega Corp., Madison, WI) has been used for amplification of targeted loci. Amplification was carried out as described previously (Promega Corporation, 2001). The total volume of each reaction was $25 \mu \mathrm{l}$. The PCR amplification has been carried out in PE Gene Amp PCR System Thermal Cycler (ABI, Foster City, CA) according to the manufacturer's recommendations. Electrophoresis of the amplification products was preformed on an $\mathrm{ABI}$ PRISM 377 genetic analyser (ABI, Foster City, CA), using $5 \%$ bis-acrilamide gel (Long Ranger ${ }^{\oplus}$ Single ${ }^{\star}$ Packs). Raw data have been compiled and analyzed using the accessory software: ABI PRISM ${ }^{\circledR}$ Data Collection Software and Gene Scan ${ }^{\circ}$. Numerical allele designations of the profiles were obtained by processing with Powertyper16 Macro. 


\section{RESULTS}

Material analysis showed presence of several people's findings. Results of anatomical and morphological analysis of teeth and bones, showed that there are remains of between 13 and 20 persons. Whereas all material from the site wasn't analyzed, number of people whose remains are found in the cave can easily be more than 20 , what future researches will show.

Human remains from the site belong to persons of different age in moment of death. Among these persons, there were also few persons of children age, what can be seen from findings of upper and lower jaws with mixed dentition, decidual teeth, and ulna bone of child 1-month old.

Radiocarbon ${ }^{14} \mathrm{C}$ analysis of bone sample showed that people whose remains were found, lived $2765 \pm 75$ before presence (today), what belongs to the period of early iron or late bronze age.

Due to absence of the positive colorimetric detection, approximated amount of DNA recovered from the tooth was less than $0,15 \mathrm{ng} / \mu \mathrm{l}$. Consequently, $5 \mu \mathrm{l}$ of DNA extract was amplified by usage of prolonged PCR protocol. STR profile was obtained only at Amelogenin - sex determining locus. This result suggested that female person was carrier of this biological specimen.

One fragment of lower jaw requires special attention (Figs. 4 and 5). This fragment is from left side of man-

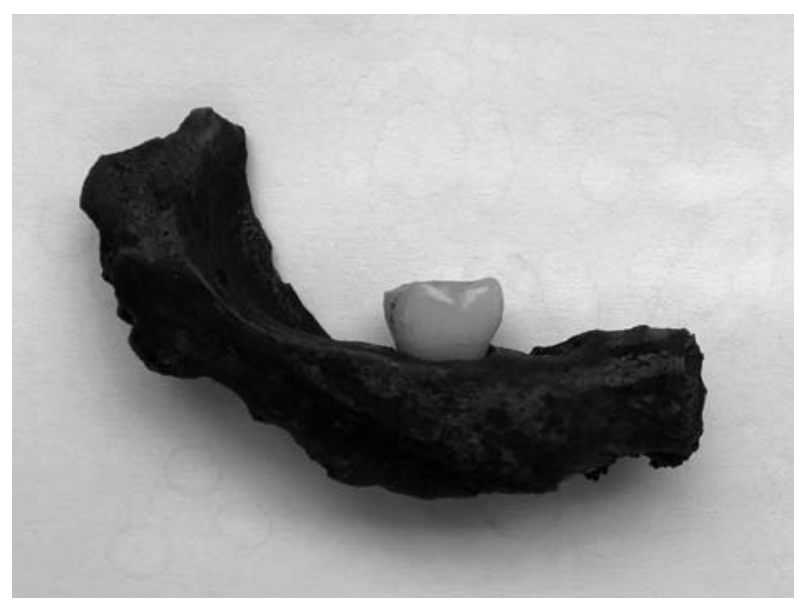

Fig. 4: One fragment of the mandibular bone with first permanent molar (external view).

dibula. The fracture lines of this fragment passed: in advance till canine's alveolus (through which also fracture line passes, back till ascendant branch of ramus mandibulae so only retromolar area with ascendant part of linea obliqua and linea milohyoidea can be seen. Anterior and posterior edges of ramus mandibulae are preserved to 25 $\mathrm{mm}$ high. Down fracture goes through canalis mandibu-

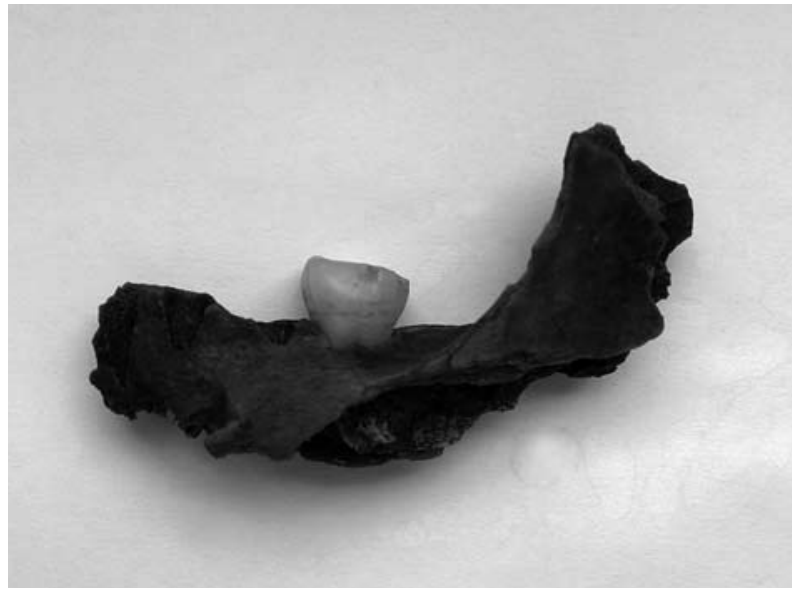

Fig. 5: One fragment of the mandibular bone with first permanent molar (internal view).

laris. Lingual side of fragment is intact, but fracture line passed through biggest part of bucal side.

Total length of fragment is $57,8 \mathrm{~mm}$.

Empty alveolus of canine, first and second mandibular premolars are signs of postmortem teeth loss. There's a first permanent molar present. Behind it, there's long retromolar area. Alveolus of second and third molar (if it existed) can't be seen, because new bone is created on that place, after those teeth are lost during the lifer (ante mortem teeth loss).

First molar alvelus and empty alveoli of first and second premolars shows bone lost of vestibular crest of alveolus, but on other sides of alveolus crests there are no signs of any bone loss. Bone loss values are:

First molar:

Vestibular alveolar crest of distal root alveolus till cementoenamel junction (CEJ): $2.6 \mathrm{~mm}$

Vestibular alveolar crest of mesial root alveolus till cementoenamel junction (CEJ): $3.5 \mathrm{~mm}$

Second premolar alveolus:

Vestibular alveolar crest is $2.6 \mathrm{~mm}$ lower than other alveolar crests, considering that complete alveolar edge is lower positioned according alveolus of first premolar.

First premolar alveolus:

Vestibular alveolar crest is $4.8 \mathrm{~mm}$ lower than other alveolar edges.

Vestibular edges of empty alveolus of caninus, first and second premolars and first molar have bone dehiscence.

Interproximal bone between canine alveolus and first premolar are well preserved, regular structure and height but interproximal alveolar bone between second premolar and first molar is reduced height, with regular structure of superficial bone lost. 
Bone around second premolar is rough, ragged with many perforations.

First left mandibular molar teeth description (36):

The maximum mesiodistal crown length - 10,95 $\mathrm{mm}$, maximum buccolingual breadth $-10,15 \mathrm{~mm}$, maximum crown height $-6,9 \mathrm{~mm}$, crown area $-111,14 \mathrm{~mm}$.

Those data showed that this tooth is smaller in all dimensions of average dimensions of this tooth, what can be found in tables of anatomical teeth measures which Konjhodžić (1978) measured for recent Yugoslav population. ASU:

Morphological features of tooth 36 according to

\section{Radical number: 2}

Anterior fovea: This sign can't be determined due to present abrasion of these teeth. This sign it's not recommended for classification in persons older than 12 years. This tooth belonged to person more than 14 years old so from that reason this sign in this case is not determined.

Groove pattern: Even if tooth has high level of abrasion, this sign can be determined. But in our case, because of abrasion, we can't be sure which type of occlusal morphology this tooth has.

Cusp number: It's not possible to determine cusp number because of abrasion, only two lingual cusps are visible on abraded oclusal surface.

Deflecting wrinkle: This tooth belonged to the person which in moment of death was more than 14 years old. From that reason, and also because of the abrasion, this sign is difficult to notice.

Distal trigonid crest: Can't be determined when abrasion of first grade is present - this molar tooth have second grade of abrasion.

Protostylid: 0

Cusp 5 /Hipoconulid/, Cusp 6 /Entoconulid/, Cusp 7 /Metaconulid/: Can't be determined due to abrasion.

\section{Tooth wear: 2}

There's wide tooth wear on occlusal surface in orovestibular direction. Abrasion erased vestibular cusps completely, also fissure system vestibular to central fissure, so on the place of this morphological features left only slope with light declivity to central fissure. Distoapproximal ridge is totally abraded. Mesioapproximal ridge has full height only in lingual part. Lingual cusps are also abraded in occlusal area, specially their external slopes,

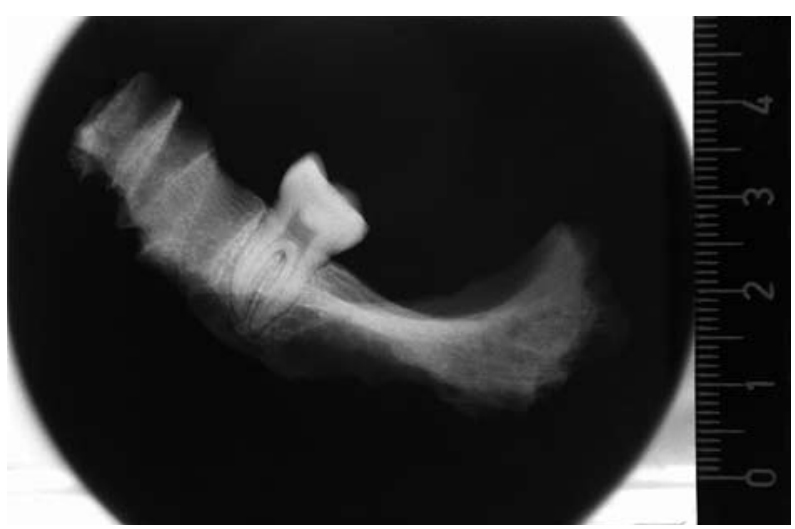

Fig. 6: X-ray of fragment of the mandibular bone with first permanent molar.

but fissure which separate mezial from distal lingual cusp is present. On mesioapproximal side of the tooth, there's contact surface on the place of the contact with second premolar during the lifetime. On the distoapproximal side, there's no abrasion on the place where contact point or surface with second molar should be present. On ECJ, on mezioapproximal surface of the tooth initial carious lesion is visible, what also X-rays analysis confirmed (Fig. 6). On the top of lingual cusps, there is white enamel opalescence. On upper third of tooth crown, on central and distal part of vestibular side and, there is enamel defect. That defect has sharp border and firm bottom, what lead us to conclusion that that defect appeared as consequence of the mechanic force, and it can be described as non complicated dental fracture on enamel echelon (fractura dentis simplex).

$\mathrm{X}$-ray analysis confirms that second molar has been lost during the lifetime (ante mortem). On the places where alveolus of second and third molars should be found, there's bone with normal trabecular structure.

On occlusal dental $\mathrm{x}$-ray film, where all mandibular bone fragments with first molar can be seen, on the place which belongs to bottom part of second molar distal root alveolus, clear shape of metal body is visible. Fragment analysis with magnifying glass showed that metal body is not on surface of the bone, but it's placed deep in the bone structure. It's supposed that this metal is broken part of instrument for tooth extraction used for second molar extraction.

\section{DISCUSSION}

Preliminary results of DNA analysis open slight possibility for additional molecular examination of discovered skeletal remains. However, before that, optimization of existing DNA isolation and amplification protocols will be required. 
Review of paleostomatological literature from the former Yugoslavia region didn't give any results which designate on therapeutic intervention like tooth extraction. Mikić (1981) gives catalogue data review of former Yugoslavia area, of all prehistorical periods, and mentioned that only on two archeological sites from iron age (Glasinac in Bosnia and Đevđelija in Macedonia) are found jaws where is evidenced ante mortem tooth loss (intra vitam).The same author also gives interesting data, that on the both sites the other teeth left have very few carious lesions or don't have it at all. That suggests that the reason why those teeth are extracted is not due to the caries which progrediated in painful diseases which leads to that tooth extraction. This fact is in accordance also with results from our study - on all 36 teeth there's no deep carious lesions. On just few teeth initial carious lesions was evidenced.

Possible reasons for second molar extraction on the fragment of the mandibular bone can be trauma, parodontological disease or caries.

Trauma: On the upper parts of buccal and distoapproximal side of crown of first mandibular molar there's enamel defect which appeared due to trauma. It's possible that this crown damage appeared at the same time when trauma affected second mandibular molar, what caused complications followed by pain and consequent tooth extraction. But it's also possible that enamel defect on first molar appeared during extraction of second molar where bad extraction technique or loosing control under instrument for tooth extraction leaded to first molar damage. Metal body inside alveolus of second molar supports this theory. This piece of metal is probably part of instrument for tooth extraction which small part fractured during tooth extraction and stayed inside postexstraction wound.

\section{Parodontological reasons}

If this tooth was extracted because of the parodontal disease, parodontal abscesses which caused the pain were the most probable reason for tooth extraction. Extraction because high level of tooth mobility (which appears in parodontal diseases) is not possible reason for extraction because canine alveolus has high degree of bone resorption comparing with bone resorption of first molar, and both of them didn't lose ante mortem. It's important to mention that alveolar bone resorption which is visible especially on the vestibular part, is not necessary consequence of parodontal disease. It's more probable that alveolar crest physiologically migrated apical because of the continuous tooth eruption and abrasion. If we know that abrasion degree of this tooth is 2 , according to ASU system, we can easily suppose that there was abrasion also on other teeth. Changes of cementoenamel junction - alveolar crest (CEJ-AC) distance are also connected with continuous tooth eruption, abrasion and facial growth, not only with pathological factors which increase the CEJ-AC distance.

Caries: It's not so possible that second molar extraction happened because of pulpal or periodontal diseases which occurred as consequence of caries progression. First molar appears in the mouth first of all permanent teeth and usually it's first affected with caries. This first molar on the bone fragment have just initial caries lesion on the cervical part, and there's no reason to believe that second molar (which appears in the mouth 6 years after first one), developed caries lesion which could lead to complications which should be the reason for tooth extraction. Even more, none of the teeth which have been found on this location had any deep carious lesions, only initial caries lesions have been found.

No matter which is the reason for this tooth extraction, it's obvious that it's extracted with some instrument what points to the presence and performance of the therapeutic interventions in this historical period. Literature review showed also some evidence of stomatologycal interventions in iron age period on area of former Yugoslavia - Mikić described one mandibula found on Glasinac site, where clear evidence of mechanical scraping is present on the place of second premolar and first molar, where scraping went to bottom of alveolus, where also one part of external alveolar bone is moved. The author supposes that this is the trace of surgical intervention of sanation of tooth gangrene or periodontitis (Mikić, 1973).

Literature didn't give any data about similar founding. Lovrinčević \& Mikić (1989) made radiological and photo documentation of osteological material with pathological changes on historical populations of Yougoslavia, but there's no evidence of foreign object located intraossealy.

The reason why this tooth is extracted is unknown. The bone which is present on the place of extracted second molar has regular structure, like the bone structure around, without any pathological changes. It means that moment of death of that person happened at least six month after tooth extraction, because it's known that physiological process of bone regeneration which can be radiological verified takes 8 weeks. After period of at least 6 moths, there's no visible difference in tooth bone structure between new formed bone on the place of extracted tooth and old bone. On our radiological film, there's no difference between the bone on the place of extracted second molar and the rest bone. It means that new formed bone is older than 6 month, e.g. moment of death of this person happened at least six months after tooth extraction.

Analysis of this mandibular fragment showed that this person had more than 14 years in the moment of 
death. Second molar wasn't in function for a long time before its extracted what can be concluded because there's no contact surface on the distoaproximal side of first molar. This person had first and second premolars, first and second molars, but third molar never existed or was also extracted, what is less possible.

Special meaning of this site location is that cave burial is characteristic of earlier historical periods. For bronze and iron age it's typical skeletal burial in tumulus and flat necropolis as much as cremation. Burial in the cave is very rare in this period.

The evidence of cave burial is present on Škocjanske Jame area, in Tominčeva jama cave (Leben, 1975), where in 190320 hallstate skeletons have been discovered and excavated. On that place also few child skeletons is found. Tombs also had been found in Ajdovska jama cave near
Nemška Vas, and in the area of Kras, southwest Alps and Panonic area as well (Korošec, 1981-1982; Leben, 1970; Guštin, 1977; Dombay, 1960; Ruttkay, 1970).

Cave burial evidence is also found in the cave Bezdanjača near Vrhovina in Lika. That site is dated in middle and late bronze age based on ceramic and metal founding (Drechler-Bižić, 1981). On that site several dozen skeletons had been found, which anthropological analysis made Pilarić G. No matter that this necropolis has been used for a long time, on that location any children skeletons never found. In the cave site near Gornji Vakuf, it's evidenced that few skeletal remains certainly belong to children, what points on different cultures of burial. This data opens many questions for which answers will give future researches on mountain Vranica area.

\section{CONCLUSION}

Researches performed in speleological objects near Bistrica and Krupa villages near Gornji Vakuf showed presence of human remains' traces. The biggest attention of explorers engaged the cave named "Cave number 5 ". In the internal part of that cave, besides ceramic fragments and one metal needle, rich anthropological material have been found, compound of numerous humans bones and teeth. Anato-morphological analysis of the one part of material showed that this site is prehistorical crypt, where are remains of at least 13 people. Radiocarbon $14 \mathrm{C}$ bone analysiss results showed that those people lived $2765 \pm 75$ before presence. The fact that anthropological material includes some remains which belonged to children, points some characteristics of burial culture of that period on area of Uskoplje. This cave crypt is the one of the biggest on this region.

Paleostomatological analysis of teeth and jaw fragments gave us clear evidence about therapeutic interventions performed in this period. X-rays analysis showed presence of the metal body inside the bone in one mandibular fragment. It's supposed that this metal is broken part of instrument used for tooth extraction.

It can also be sad that, based on those modest researches, that caves in area of Bistrica and Krupa villages, the traces of human abode in different history periods are found, and some of those findings very clearly and directly point on their ritual usage.

\section{ACKNOWLEDGEMENT}

In the exploration in July 2003 participated: Amila Zukanović, Tarik and Emir Dizdarević, Davor Dautbegović, Ivica Bošnjak, Mirjana Palavra, Ajna and Jasminko Mulaomerović. In the exploration in No- vember 2003 participated: Ilhan Dervović, Jasminko Mulaomerović, Mustafa Duratbegović, Amir Topčić, Amila Zukanović, Tarik Dizdarević, Edis Duvnjak i Samir Pokvić. 


\section{REFERENCES}

Bronk, R.C., 1978: Radiocarbon calibration and analysis of stratigraphy: the OxCal program. - Radiocarbon 37: 425-430.

Bordeaux, A., 1987: "Narodna Bosna”. - In: Fojnica kroz vijekove.- Skupština opštine Fojnica \& SOUR "Veselin Masleša”, Fojnica - Sarajevo. (According to issue of PLON, Paris, 1904.).

Christy, G., Turner, I. I., Christian, R., Nichol, G. \& Richard, S., 1991: Scoring procedures for key morphological traits of the permanent dentition - The Arisona State University Dental Anthropology System. - In: Kelley M. A., Larsen C. S. (eds). Advances in Dental Anthropology. New York:Wiley-Liss, Inc., pp.13-31

Dombay, J., 1960: Die Siedlung und das Graberfeld in Zengovarkony: Beitraege zur Kultur des Aeneolithikums in Ungarn. - Archaeologica Hungarica - Dissertationes Archaeologicae Musei Nationalis Hungarici, s.n 37, Budapest: Verlag der Ungarischen Akademie der Wissenschaften, pp. 235.

Drechler-Bižić, R., 1981: Nekropola brončanog doba u pećini Bezdanjači kod Vrhovina. - Vjesnik arheološkog muzeja u Zagrebu XII-XIII/1979-1980: 27-78 + I-XLVI.

Guštin, M., 1977: Poročilo o izkopu kulturnih slojev v Levakovi jami. - Arheološki vesnik 27: 260-282.

Konjhodžić-Raščić, H. (1978): Prosječne anatomske mjere zuba jugoslovenske populacije i postojanje seksualnih razlika u veličini zuba.- Univerzitet u Sarajevu, Sarajevo, (doktorska disertacija).

Korošec, P., 1981-1982: Kult mrtvih v luči najnovejših raziskav v Ajdovski jami pri Nemški vasi. - Poročilo o raziskovanju paleolita, neolita in eneolita v Sloveniji 9-10: 15-20.

Leben, F., 1970: Značilnosti in pomen nekaterih arheoloških jamskih najdišč na področju jugovzhodnih Alp. - In: Adriatica praehistorica et Antiqua : Zbornik radova posvećen Grgi Novaku, XXXIV, pp. 739, Zagreb: Sveučilište u Zagrebu : Arheološki institut Filozofskog fakulteta.
Leben, F., 1975: Škocjanske jame (Škocjan), Tominčeva jama. - In: Arheološka najdišča Slovenije, p. 132133, SAZU \& DZS, Ljubljana,.

Lovrinčević, A., Mikić, Ž., 1989: Atlas osteopatoloških promjena na istorijskim populacijama Jugoslavije. - "Svjetlost", Sarajevo.

Marijan, B., 1988: Gradina, Krupa, Gornji Vakuf . - In: Arheološki leksikon Bosne i Hercegovine, T. 2., Zemaljski muzej BiH, Sarajevo.

Martinčević, F., 1901: Narodna pričanja iz Bosne. Glasnik Zemaljskog muzeja, XIII: 468-471.

Mikić, Ž. (1981): Stanje i problemi fizičke antropologije u Jugoslaviji (praistorijski periodi). -Akademija nauka i umjetnosti Bosne i Hercegovine, Sarajevo.

Mulaomerović, J., 2004: Tragovi kultura u pećinama okolice Gornjeg Vakufa u Bosni. - Speleozin, XII, 17: 60-63.

Promega Corporation, 2001: Promega Corporation PowerPlex $16^{\circledast}$ system Technical Manual. - Promega Corporation, Madison (WI).

(1996): QuantiBlot ${ }^{\circledast}$ Human Quantification Kit User's Manual. - The Perkin-Elmer Corporation, Foster City (CA).

Ruttkay, E., 1970: Das jungsteinzeitliche Hornsteinbergwerk mit Bestattung von der Antonshöhe bei Mauer (Wien 23). - Die Ausgrabungen Josef Bayers in den Jahren 1929-1930. Mitteilungen der Anthropologischen Gesellschaft Wien 100: 70-115.

Stuiver, M. \& Reimer, P. J., 1986: A computer program for radiocarbon age calculation. - Radiocarbon $28(2 \mathrm{~B})$ : 1022-1030.

Topčić, A., 2000: Speleologija u Gornjem Vakufu (I). - Speleobih V, 5: 20.

Zukanović, A., 2004: Preliminarni izvještaj o oseo-dentalnom humanom materijalu iz pećine iznad vrela Krušnice kod Gornjeg Vakufa.- Naš krš, VII (in print). 